\title{
Digital Economy Role in Modern Social and Economic Relations Management
}

\author{
Natalia Ershova \\ Department of Foreign Policy Public Administration \\ The Federal State Budget-Funded Educational Institution of \\ Higher Education «Diplomatic Academy of the Ministry of \\ Foreign Affairs of Russian Federation» \\ Moscow, Russia \\ nataly_ershova@mail.ru
}

\author{
Ruslan Shangaraev \\ Department of Foreign Policy Public Administration \\ The Federal State Budget-Funded Educational Institution of \\ Higher Education «Diplomatic Academy of the Ministry of \\ Foreign Affairs of Russian Federation», \\ Moscow, Russia \\ Shang143@mail.ru
}

\author{
Tatiana Kosareva \\ The Federal State Budget-Funded Educational Institution of Higher Education «Diplomatic Academy \\ of the Ministry of Foreign Affairs of Russian Federation», \\ Moscow, Russia
}

\begin{abstract}
The article is devoted to the actual problem of analysis of the digital economy impact on the current state of world economy, the problem of transition to a qualitatively new level to meet the requirements of digital civilization. The authors suggest a number of specific constructive proposals to adapt the Russian economy to the new intellectual and information era. Large-scale technological changes are accompanied by changes in the institutional structure of society. On the current state of the "digital economy" in the context of international economic relations. Integrated author's influence of the "digital economy" on the current state of the world economy, on the problem of transition to a qualitatively new level associated with the requirements of digital civilization. Methods of the study. In the course of the study, simulation modeling with the use of economic and logical methods was used, allowing to reach the methodology of optimizing the ratio of development of a digital economy.

Conclusions and Relevance Although the digitalization of the economy has positive consequences (trade expansion, productivity growth, competition, job creation, etc.), it also has one significant drawback connected with a serious transformation of jobs, which can lead to an explosive increase in technological unemployment, especially in developing countries, as the World Bank warns. As a result, the competition among the middle class will considerably increase, which can lead to the wages stagnation.
\end{abstract}

Keywords: digital economy, world economy, joint consumption, digital technologies

\section{INTRODUCTION}

The term "digital economy" emerged in 1995 with the intensive growth of information and communication technologies, and it was directly connected with the development of the Internet and mobile communications, which are the basic technologies of the digital economy.

It is clear that as a result these processes have affected all sectors of the economy and social activities, including production, health, education, financial services, transport, etc.

In a broad sense, the digital economy (as defined by the World Bank) is a system of economic, social and cultural relations based on the use of digital information and communication technologies. In today's economy, the digital sector companies come to the fore and become growing points that provide the economy with a digital resource. If at the beginning of the $\mathrm{XX}$ century the main locomotives of the world economy were big oil, metallurgical, engineering and mining enterprises, now the largest companies are representatives of the digital economy sector.

Describing the economic component of digital economy, it should be noted that commercial efficiency reflects the direct financial implications for its participants. Budget efficiency shows the financial implications of a project for a budget of one level or another (federal, regional or local). The national economic efficiency of digital economy is usually considered for large projects. It takes into account economic costs and results that go beyond the direct financial interests of state management [12]. Scaling down the cost of processing, storage and transmission of data and the development of infrastructure bring humanity to the threshold of the most ambitious and a new stage of the digital revolution.

The use of large databases and the development of technological infrastructure have caused a large-scale digital transformation of the society. Suffice to say that the previous 
is happening that goes beyond the previous concepts frames. [13].

However, the Internet performance capability to trade has also been taken into account and has thus become a part of the digital economy definition. The IT based business activity has been mentioned as a component of the digital economy in the U.S. Department of Commerce report "The Emerging Digital Economy" [Margherio et al.]. This tendency was even more clearly manifested in the collection "Understanding the Digital Economy" [Brynjolfsson, Kahin,]. There both editors and coauthors [Brynjolfsson, Kahin,; Kling, Lamb] attributed Electronic Commerce to the digital economy as it was a period of the dot-com bubble.

Besides that, the above mentioned formulations recorded the first appearance of two major components of the digital economy definition. The first one is the components differentiation. For example, Rob Kling and Robert Lamb [Kling, Lamb] in their work based on the publication of Lynn Margherio [Margherio et al], pointed out four main components of the digital economy:

1. Digital products and services. This component includes products provided by digital technologies, as well as types of services mainly supplied in a digital form (i.e. online information services, software sales, E-education, etc.).

2. Mixed digital products and services. This category includes the retail sale of real goods (such as books, flowers, hotel rooms, and related sales and marketing).

3. Services or production of goods dependent on it. This group covers services whose provision is critically dependent on information technology (for example, accounting services or complex technical projects), the production of real goods, in the process of which the use of information technology is crucial (such categories of goods that require high-precision numerical control machining or chemical plants controlled by computers).

4. A segment of the industry that serves the above mentioned three segments of the digital economy is under consideration. It examines the IT sector products and services that are mainly designed to serve the three previously mentioned components of the digital economy. This includes manufacturers of network equipment and personal computers, as well as firms engaged in IT consulting. Some analysts apply more extensive concepts to the IT industry and they put communication equipment, including television, radio broadcasting and communication services in this list. Such differentiation is a kind of recognition that ICT-based products and related services are components of the digital economy.

\section{RESULTS}

Under the term "digital economy" we understand the modern type of management, characterized by the predominant role of data and methods of management as a determining resource in the field of production, distribution, exchange and consumption.

It is important to take into account that the digital economy generates new effects associated with the transformation of 
economic relations of information nature. In other words, there grows a number of behavior models based on data, which often do not meet the qualitative requirements of completeness, reliability and relevance. The number of behaviors that use distorted information or intentionally distort information is increasing. Economic opportunism involves misuse of data on competitors, markets and technologies. The number of economic crimes in cyberspace is increasing, causing firms to suffer losses unknown to the traditional economy. The production driver is more often turns into the speed of obtaining and processing particular and significant data, while planned disinformation became an element of unfair competition. Economic science cannot ignore such problems. The old economic categories, terminological apparatus, interpretation of certain concepts are subject to changes. The development of research in the field of institutional theory, operating in such categories as information, transactions, in our opinion, can contribute to overcoming scientific difficulties [5].

The regional integration mechanism contributes to the development of digital trade and the integration of digital markets [14]. Nowadays, the digital economy is named as one of the priority directions in the strategy of scientific and technological development of Russia. A full-fledged systematic digitalization of the Russian economy will become a platform for qualitative changes in its structure and longterm opportunities.

The basic component of the current economic organization is the work with data and the use of information and communication systems in the management process. The ongoing transactions are the data exchange and their interpretation, which determines the nature of future interactions, which in its turn leads to the formation of relations of some participants with others and the rules of behavior, change of behavior motives, transformation of the value system. Through using the apparatus of information theory and synthesizing it with methods of analysis of transaction costs, the Institutional theory has significant opportunities for further economic relations research [6].

Large-scale technological changes that involve people using data and communication technologies, interact with production innovations and are accompanied by modifications in the institutional structure of society [17]. It is necessary to meet the following conditions to implement social and innovative society development:

1. Firstly, linking-up a significant number of community members to produce and broadcast new knowledge. It is necessary to spread and multiply implicit and inaccessible to other individuals knowledge which is detached from social interaction.

2. Secondly, the creation of an "open access" space for the exchange and dissemination of knowledge. Reduction of barriers of interaction, geographical, linguistic and other obstacles and development of new opportunities, in the form of the emergence of social networks of a General or specialized nature.
It becomes possible to move to a new level of economic processes management due to increasing data flows. Modern data retrieval systems allow to computerize the process of managerial decision-making, allow far more detailed analysis of economic activity [15]. Modern databases enable users to analyze and predict economic processes at the macro level, at the level of individual regions, industries and enterprises [16]. Modern smartphones, digital devices, the Internet of products make it easier to obtain data directly from economic agents. The data got from such devices permit to create digital models of consumers, technological processes, that leads to resource savings, optimization of procurement systems, optimization of the finances use, etc. [7]

\section{DISCUSSION}

Digital technologies are actively used by many Russian companies. New business models of Gazpromneft have been developed on the basis of digital solutions. One of the structural divisions of Gazpromneft, the "Center for Digital Innovation " is focused on applying the most modern technologies to improve the efficiency of individual business processes and the work of all company divisions as a whole. The "Center for Digital Innovation" is engaged in digitalization of logistics, processing and sales systems. All processes that take place after oil has been extracted from the subsoil are being improved. The goal is to build a single chain of plant management, logistics and customer interaction in order to manage it as a single organism, taking into account not only the specifics of today, but also the possibility of rapid adaptation to the needs of the market.

The digital economy not only offers opportunities, but also creates threats. There are difficulties in taking advantages of new opportunities, for example, because of low levels of digital skills and insufficient penetration of technologies both within and between countries [Dahlman et al. Inclusion in the digital economy can have a negative impact due to transition period effects (lack of resources, opportunities, institutions, relationships) [Murphy, Carmody.]; high volatility of digital companies in developing countries [Foster, Heeks.]; marginalization of workers from developing countries on the account that the digital economy is developing mainly in the countries of the global North [Martin.]. The growth of the digital economy can result in certain losses for developing countries, for example, the increase in vulnerability created by the necessity to balance digital security and privacy [Maniyka et al].

The contribution of the authors to the development of the theme lies in the fact the" digitalization " of the economy brings positive consequences (extension of trade, increased productivity and competition, creation of jobs, etc.), it also has one significant drawback closely connected with crucial job transformation that could lead to an explosive increase in technological unemployment, especially in developing countries, as the World Bank warns. [8, 21, 22]. As a result, competition among the middle class workers will increase significantly, which can result in stagnation of wages. the article distinguishes the author's position from other articles of domestic and foreign scientists on this topic. 
DOI: 2018SPbWOSCE221132.

\section{REFERENCES}

[1] The largest and most expensive companies in the world [Electronic resource]. Available at: https://allbanksworld.ru/rejtingi/kompanii-mira/ (Accessed: 01 June 2019).

[2] Digital economy: History and prospects [Electronic resource]. Available at: http://ar2016.rostec.ru/digital-history (Accessed: 01 June 2019).

[3] Andreev Carp. "Peer-to-peer Economics", Litres, 2018, 330 p. ISBN: 9785041455347.

[4] E. Brynjolfs-son and B. Kahin, "Understanding the digital economy: data, tools, and research", Cambridge: press of Massachusetts Institute of technology, 2000.

[5] G. Barnabas, "Digital technologies and growth of the world economy", Drucker's Bulletin, 2015, no. 3 (7), pp. 73-80.

[6] K. A. Semjachkov, "Digital economy and its role in the management of modern socio-economic relations, Modern Management Technology, 2017, no. 8 (80), art. 8001 [Electronic resource]. ISSN 2226-9339. Available at: https://sovman.ru/en/article/8001.

[7] B. Berbers, "Towards the digitalization of the Russian economy: problems and prospects", the Journal "Management of economic systems: electronic scientific journal" is included in the WAC List [Electronic resource]. Available at: http://uecs.ru.

[8] "Digital Dividends: World Development Report", World Bank, 2016 [Electronic Resource] Available at: http://www.worldbank.org/en/publication/wdr2016.

[9] O. V. Petko, "Investments in human capital as a factor of economic security of the country", Creative economy, 2012, no. 5 (65), pp. 46-49 [Electronic Resource]. Available at: http://bgscience.ru/lib/4718.

[10] Network pictures: Facebook Facebook and Twitter HR-Journal [Electronic Resource]. Available at: http://hr-portal.ru/blog/setevyekadry-rekrutery-osvaivayut-facebook-i-twitter.

[11] N. A. Ershova, "Development of management decisions in the system of effective management", Monograph, MIRBIS Institute, 2015, pp. 213220.

[12] N. Ershova, R. Shangaraev, M. Kostyshak, N. Safonova, V. Sukhova, E. Popkova, and E. Tinkova. "Evaluation of the effectiveness of innovative projects in the energy sector", E3S Web of Conferences.
[13] B. Rumana and H. Richard, "Definition, concept and measurement of digital economy", Bulletin of international organizations: education, science, new economy, 2018, T. 13, no. 2, pp. 143-172.

[14] O. V. Biryukova and A. V. Daniltsev, "When cooperation does not develop: global management of digital trade", Bulletin of international organizations: education, science, new economy, 2019, T. 14, no. 1, pp. 7-20.

[15] S. A. Afontsev, "New trends in the development of the world economy", World economy and international relations, 2019 , T. 63, no. 5, pp. 3646.

[16] N. M. Rozanova, "Evolution of the firm in the digital economy", World economy and international relations, 2019, T. 63, no. 8, pp. 21-28.

[17] M. G. Khokhlova and I. I. Khokhlov, "Youth in the Russian labor market", World economy and international relations, 2018, T. 62, no. 9, pp. 88-96.

[18] D. V. Smyslov, "Evolution of world globalization of economy: modern trends", World economy and international relations, 2019, T. 63, no. 2, pp. 5-12.

[19] G. Quinones, B. Nicholson, R. Heeks, "Literature review on eentrepreneurship in emerging economies", Entrepreneurship in BRICS countries (R. L. La Rovere, L. de M. Ozório, L. J. de Melo (EDS)), 2015.

[20] S. Nekrasov, N. Nekrasova, V. Berkut, A. Nekrasov, I. Lambaeva, and L. Meshcheryakova, "The essence of socio-economic management". DOI: https://doi.org/10.2991/ispcbc-19.2019.2.

[21] A.V. Vernikov, "The Drivers of Institutional Change in a Post-Socialist Economy: The Case of Deposit Insurance Introduction in Russia", Journal of Institutional Studies, 2019, T. 11, no. 1, pp. 129-143.

[22] I. A. Mayburov, "Challenges and Prospects of Taxation IN the Digital Economy: Symposium "Theory and Practice of Tax Reforms" As A Case of Focused Discussion in The Post-Soviet Space", Journal of Tax Reform, 2019, T. 5, no. 2, pp. 96-106.

[23] B. Ostromouhova and J. Waldfogel, "Digital Renaissance: What Data and Economics Tell Us About the Future of Popular Culture Princeton", Nj: Princeton University Press, 2018, Laboratorium: 2019, no. 2, pp. 187-190. 